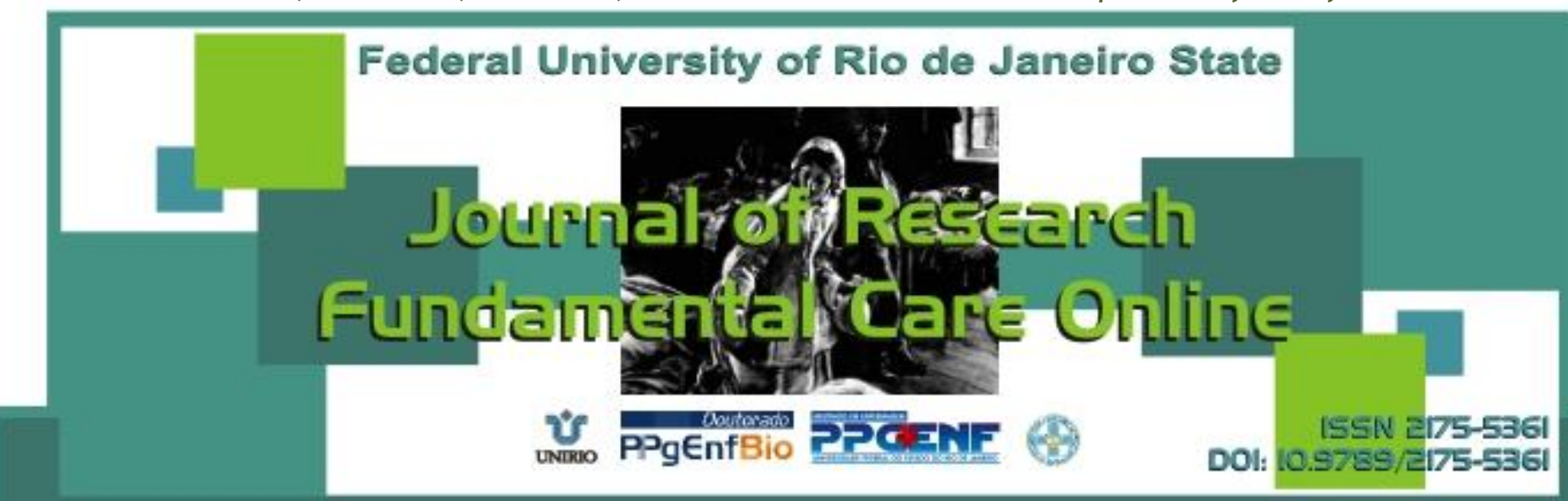

\title{
RESEARCH
}

\section{Perspective of care for users with arterial hypertension in a family health}

\section{Unit}

Perspectiva de cuidado para usuários com hipertensão arterial em uma unidade de saúde da família

Perspectiva de cuidado por usuarios con hipertensión arterial en una unidad de salud de la familia

Margot Agathe Seiffert ${ }^{1}$, Maria de Lourdes Denardin Budó ${ }^{2}$, Simone Wünsch ${ }^{3}$, Margrid Beuter ${ }^{4}$, Maria Denise Schimith ${ }^{5}$

$\leadsto$ ABSTRACT

Objective: To know the practices developed for users with arterial hypertension. Method: A descriptive-exploratory research, with qualitative approach realized in people with arterial hypertension living in the coverage area of a Family Health Unit of a city in southern Brazil. The data collection occurred during the months of February and March 2011 through semi-structured interviews. To analyze the data was used the thematic analysis. Results: From data analysis emerged the following categories: care with food; medication care, care with physical activities; care in maintaining emotional balance; popular care. Conclusion: The study highlights the importance to know the care developed for hypertensive users in order to better lead the health actions in this public, valuing their practices and paying attention to the difficulties experienced for them in the realization of such care. Descriptors: Chronic disease, Hypertension, Culture, Health behavior, Nursing.

Objetivo: Conhecer as práticas de cuidado desenvolvidas por usuários com hipertensão arterial. Método: Pesquisa descritiva exploratória, de abordagem qualitativa realizada com pessoas com hipertensão arterial moradoras da área de abrangência de uma Unidade de Saúde da Família de um município do sul do Brasil. A coleta de dados ocorreu nos meses de fevereiro e março de 2011 por meio de entrevista semiestruturada. Para analisar os dados utilizou-se análise do tipo temática. Resultados: Da análise dos dados emergiram as seguintes categorias: cuidados com a alimentação; cuidado medicamentoso; cuidados com atividades físicas; cuidado em manter o equilíbrio emocional; cuidados populares. Conclusão: Destaca-se a importância de conhecer os cuidados desenvolvidos por usuários hipertensos, a fim de melhor conduzir as ações em saúde a esse público, valorizando suas práticas e atentando para as dificuldades vivenciadas por eles na realização desses cuidados. Descritores: Doença crônica, Hipertensão, Cultura, Conduta de saúde, Enfermagem.

RESUMEN

Objetivo: conocer las prácticas de cuidado desarrolladas por los usuarios con hipertensión arterial. Método: investigación descriptivo-exploratoria, de abordaje cualitativo, realizada con personas con hipertensión arterial que viven en el área de alcance de una Unidad de Salud de la Familia de una ciudad del sur del Brasil. Los datos fueron recolectados durante los meses de Febrero y Marzo de 2011 a través de entrevistas semi-estructuradas. Para analizar los datos se utilizó el análisis temático. Resultados: del análisis de los datos surgieron las siguientes categorías: Cuidado con los alimentos; cuidado de la medicación; cuidado con las actividades físicas; cuidado en mantener el equilibrio emocional; el cuidado popular. Conclusión: se destaca la importancia de conocer los cuidados desarrollados por los usuarios hipertensos, para el mejor cumplimiento de las acciones en salud para ese público, valorando sus prácticas y prestando atención a las dificultades experimentadas por ellos en la realización de eses cuidados. Descriptores: Enfermedad crónica, Hipertensión, Cultura, Conducta de salud, Enfermería

${ }^{1}$ Master in Nursing of the Postgraduate Program in Nursing (PPGEnf), Federal University of Santa Maria UFSM/RS. Member of the Research Group Care, Health and Nursing. E-mail: margotenfer@gmail.com. ${ }^{2} \mathrm{PhD}$ in Nursing. Associate Professor, Department of Nursing and of PPGEnf UFSM/RS. Member of the Research Group Care, Health and Nursing. E-mail: lourdesdenardin@gmail.com. ${ }^{3}$ Master in Nursing. Nurse at the Municipal São Luiz Gonzaga. Member of the Research Group Care, Health and Nursing. E-mail: simone . simone.wunsch@gmail.com. ${ }^{4}$ PhD in Nursing. Associate Professor, Department of Nursing and of PPGEnf UFSM / RS. Member of the Research Group Care, Health and Nursing. E-mail: margridbeuter@gmail.com. ${ }^{5}$ Doctor of Science. Adjunct Professor, Department of Nursing and of PPGEnf UFSM/RS. Member of the Research Group Care, Health and Nursing. E-mail: ma.denise2011@gmail.com. 


\section{INTRODUCTION}

he morbidity profile of the world's population has been showing modifications, which are related to the increase in chronic diseases. These diseases are characterized by continuing need for care, from the diagnosis.

Among chronic diseases, there is the Systemic Arterial Hypertension (SAH), a disease that affects a considerable number of people. It is characterized by high blood pressure and sustained. ${ }^{1}$ It is considered an asymptomatic clinical course of slow that without proper treatment, can cause serious complications, affecting the quality of life of the individual. ${ }^{2}$ Thus, hypertension represents an important public health problem because it is one of the major risk factors for cardiovascular diseases, currently responsible for high rates of morbidity and mortality. ${ }^{3-4}$

Treatment of hypertension demand monitoring long-term changes in habits and lifestyle and medication, sometimes for a lifetime. ${ }^{3}$ Due to these factors, the control and treatment adherence are considered very low in the world ${ }^{3}$, demonstrating the need for special attention to those involved.

Corroborating, the authors stress that health professionals encounter difficulties and resistance from users to adhere to the care of this disease, especially when it involves the adaptation factor. ${ }^{5}$ Because of hypertension have a feature asymptomatic, adaptation to care becomes more difficult, and require changes in lifestyle.

In this sense, health professionals have looked beyond the biological references to support their practices. They recognize that the actions required to adhere to treatment and long-term care are deeply intertwined with culture, ie with the lifestyles, habits, routines and rituals in people's lives. ${ }^{6}$ Culture can be understood also as a set of elements that mediate and qualify any physical or mental activity, which is not determined by biology, including values, symbols, norms and practices. ${ }^{7}$

Thus, it is important to know how people lead the cares with hypertension because they are influenced by cultural, beliefs, customs and concept of health and illness they have. Consider the different practices of care allows health professionals to understand the way of thinking and acting of individuals toward their health problems, facilitating communication, allowing for consistent care and promoting health interventions. ${ }^{8}$

Still, knowing the care practices can be viewed as users care and what difficulties are. Thus, new strategies for the control of hypertension can be traced, in order to reduce its complications and provide quality of life for users.

Given the above, the study aimed to identify care practices developed by users with hypertension, residents of the area covered by a Family Health Unit (FHU). 


\section{METHODOLOGY}

This is a qualitative, descriptive and exploratory research, developed in the catchment area of a FHU located in the state of Rio Grande do Sul. By cover a territory extensive, this FHU is divided into two areas, each with six micro areas. It is worth mentioning that the micro areas have large socioeconomic and cultural disparities, configuring a heterogeneous territory.

Therefore, we chose to follow the guidelines for authors in terms of diversification of data. In qualitative research, diversification is the main selection criterion, as these are used in order to present the complete picture possible of the problem. ${ }^{9}$ Thus, given the diversification criterion, we tried to choose users from different micro areas, so that, if it came to the greatest possible diversity in view of their socioeconomic differences.

The choice of participants was guided by the following inclusion criteria: having hypertension, to be older than 18 and reside in micro areas of FHU. The search started from the master record of the families of Community Health Agents The number of study subjects was defined by data saturation, which marks the time when the search for new participants is not new for the research. ${ }^{9}$

For data collection we used semi structured interview consists of two parts. The first addressed questions about the socioeconomic characteristics of the participants and the second, questions about the practice of care for hypertension. The interviews took place in February and March 2011 and data were analyzed using thematic analysis, which consists in discovering the meaning units that make up a communication. ${ }^{10}$

Understanding the need to ensure and enhance the ethical conduct throughout the course of the study, we considered the guidelines and rules of Resolution 196/96 of the National Health Ministry of Health, governing research involving humans. ${ }^{11}$ Thus, the study was conducted with the approval of the municipality and the institutional Ethics Committee in Research of the Federal University of Santa Maria, under the Certificate of Appreciation Presentation for Ethics 0326.0.243.000-10 number.

To preserve the identity of the subjects was used the letter "S" of the subject, then the number on the order of the interview ( $\mathrm{S} 1, \mathrm{~S} 2$, and so on). All participants read and signed the consent form.

\section{RESULTS AND DISCUSSION}

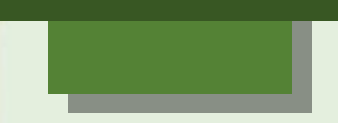

The study subjects were 10 users with hypertension, nine women and one man. The age ranged between 38 and 62 years old, and most were between 50 and 60 years old, two were under 40 and two aged over 60 . About marital status, seven were married, two widows and one was single. 
Regarding education, five had primary education Incomplete, two had full primary school, two the secondary school and only one person had completed higher education. Regarding occupation, the four were housewives, two maids, a pastry, a seamstress, one vigilant and a retired teacher.

The data analyzed unveiled about five categories of care practices with hypertension developed by the participants. They are: nutritional care, medical care, care with physical activities; care in maintaining emotional balance; popular care.

\section{Nutritional care}

The data analysis allowed highlighting the remarkable presence of nutritional care represented especially by controlling the use of salt and fat in meals.

[...] First thing I care is food, salt and fat, and even takes many months to frying [...] Now I look for more vegetables. I think it's important that care is little, but it makes a difference (S3).

The feeding, I started controlling, alcohol also decreased, every night I took one or two cans of beer, now only take on Sundays at the BBQ nothing more [...] also salt the food, decrease the fat also (S7).

Users to discover Hypertension was passed to adopt a different diet, reducing salt and fat, and vegetables consumed in greater quantity. The decrease in alcohol use was also highlighted. These data were also highlighted in a study of the care performed by men with diabetes and hypertension, which have adopted a diet considered healthier, with a lower consumption of sodium chloride and high fat foods. ${ }^{12}$ These care practices are part of the non-drug treatment of hypertension, which includes weight control, adequate dietary pattern, reduced fat and salt intake, moderation in alcohol consumption, in addition to the regular practice of physical exercise. ${ }^{3-4}$

The testimony demonstrated the commitment and concern to reduce the use of salt to improve the control of hypertension. However, it can be noticed, too, the difficulty in performing this care.

[...] I am already abused more salt, and it just could not control myself yet, is if I'm going to do a green salad as well, I cannot eat it weak salt, I have to feel that a little salt in salad that's my bad (S1).

Not much, but I feel the salt, you feel the taste of salt (S6).

[...] I generally like unsalted, but I have a heavier hand, then when I see when I pounce nerves, gives a changed (S2).

The difficulties of controlling the amount of salt used in meals relate to the way they prepare the food and exemplified. These need to be tempered with a sufficient amount of salt to your liking feel appropriately. Thus, one can say that these behaviors are seen by 
participants as natural as they are common habits, influenced by the customs of the families and their cultures. Therefore, changing them requires time and dedication user and health professionals.

It appears, therefore, that the respondents are aware about the need to reduce salt intake, but point out difficulties in carrying out this care. Corroborating these findings, a study on adherence to non-pharmacological treatment among hypertensive patients revealed a dichotomy between perception and action, since the change in diet is perceived as necessary, but not so effectively in practice users. ${ }^{13}$

This dichotomy is due to the fact that usually the user with hypertension diet restricts food habits ingrained in their culture, it makes him compare eating habits to a punishment, since it requires replacement of foods commonly consumed by other foods considered healthier, but not so tasty to the palate. ${ }^{13}$ Thus, it is necessary to strengthen the professional responsible for the care plan user with hypertension should enable active participation of it in all spheres of their treatment, including in your diet plan, trying if possible to keep some foods in the diet of your own, so it really is then. ${ }^{12}$

Paying attention to these issues, the Ministry of Health has signed agreements with the Brazilian food industry in order to reduce the sodium content in processed foods in Brazil. Thus, the reduction of sodium in Brazilian consumption, according to the agreements, will reach 20.000 tons by 2020. The government aims to achieve the recommendation of the World Health Organization, that each person consume no more than five grams of sodium per day. Currently, the daily consumption of Brazil is estimated at 12 grams per person. ${ }^{14}$

Thus, the reduction in salt intake, care for the treatment of essential hypertension, becomes a concern and responsibility of government, not just individuals. In addition, health professionals have an important role in this context, actions promoting health education among these users.

\section{Medication care}

Another caution mentioned by participants was the use of antihypertensive medication. For some, taking medication is considered a primary care practice with hypertension.

The main care is not to forget the medicine [...] I try to control the salt, from time to time, but not always, I do walk, an exercise from time to time is good (S5).

I think I have to take medicine just right (S8).

[...] Is not only taking the medicine too, is not enough, we have to take care, food [...] look never be without the medication at home, I never cease to catch on, always about five, six days earlier not to run out the remedy (S1).

The participants consider important the non-pharmacological care, as the control of salt and physical activity. However, it became evident that the utmost care is with medication. This cannot be forgotten or missing and needs to be taken correctly.

According to some authors, the importance given to the medication by the users is a result of the mandatory use of medicines in everyday with chronic diseases. Therefore, this practice of care is commonly emphasized in their speeches. ${ }^{15}$ Still, it is noted that, not infrequently, users face difficulties in following the non-drug treatment, which requires 
changes in diet, decreased physical inactivity and smoking cessation. Thus, caution is replaced pharmacological role in the treatment of hypertension.

In the context of these considerations, it is important to note that while the use of medication is quoted as essential for the control of hypertension, some users have reported difficulties and carelessness as to the practice of care, either by forgetting to take medicine or be a compulsory care often difficult to incorporate into daily life.

[...] You have a person you stay so dependent on medication, have to be taking medicine [...] have to have that commitment, if not take no improvement (S9).

Ah! Sometimes I forget! (medication) Yesterday I forgot. Today I took four (pills), I took the Hydrochlorothiazide of yesterday and today, so I had to take two, and Captopril yesterday and today. Then I took four! (S6).

The requirement to use the antihypertensive medication could mean dependence, ie, loss of control of his own body; he can no longer maintain the pressure levels normalized, requiring the continued use of the medication. In this sense, it is noteworthy that the majority of chronic diseases require a relearning body, involving the adoption of preventive measures, medical schemes and submission technologies, reflecting the identity of the person. ${ }^{16}$

Testimony reveals that the forgetting to take medication at a certain time, the participant eat all the pills at once, in order to correct the fault. This practice can cause damage to health, for example, the sudden drop in blood pressure. So, make use of antihypertensive drugs is still a hard habit to incorporate into the everyday life of this user even having hypertension for years.

This fact highlights the need for further health education continued, even for those users who are no longer living with the diagnosis of hypertension. It is necessary to motivate and encourage continuity of care, the difficulties of identifying each user and allowing the construction joint strategies to minimize such difficulties. Thus, the authors emphasize that health education is consolidated as timely and essential resource to attitude change, whose aim should be not only the control of hypertension, but also the pursuit of better health and well-being hypertensive patients. ${ }^{17}$

While on the pharmacological care, it was found that the medication is sometimes interrupted due to the absence of signs and symptoms associated with hypertension.

[...] As in her pregnancy (the daughter) was high (blood pressure) and then moved, improved, I would not need to take [...] when I took gave me a headache, I was there, drank and felt better (S9).

It is very common for the user to make use of drug therapy when he notices some physical discomfort such as headache. When the discomforts are no longer perceived medication is seen as unnecessary. This demonstrates that there is a self-management of medication due to perceived symptoms. This finding has been found in other studies showing that patients also interrupted the drug treatment because they believe that blood pressure was controlled and the need to use drugs was remembered as unpleasant physical changes were perceived. ${ }^{15,18}$ 
The ignorance of the chronic nature of hypertension can also be attributed to the interruption in the use of antihypertensive medications. SAH, like other chronic diseases requires continuous care, and in some cases, the medication needs to be used continuously without interruption. In research conducted with hypertension, it was concluded that they were unaware of chronic hypertension and the necessity of realization of antihypertensive treatment for the rest of their lives. These subjects are therefore considered to be more susceptible to complications of the disease, as they believe that in the absence of signs and symptoms do not require further treatment. ${ }^{19}$

Furthermore, the neglect of the use of medicines may be an attitude of denial of health condition.

[...] There was a time I did not accept, nor took the drugs [...] there are days when I throw the drugs, then I want to take a one that has no problem, then let the drugs side [... ] then I think: no use, I have to take for the rest of my life (S10).

The speech reveals that, in this case, has knowledge about the chronic nature of hypertension, however, the remedies remind the disease, so they are sometimes forgotten. This finding corroborates another study conducted with people with hypertension, which showed that the intake of antihypertensive medication did remind patients of their chronic health condition. Thus, stop taking medications or taking them when they felt needed was a way to deny or control their disease. ${ }^{20}$

\section{Care with physical activities}

The physical activity was also cited as a way to care for research participants.

[...] I do gym too, I go to water aerobics [...] do a lot of movement, that sitting is not good for anyone [...] How good thing I learned at the academy, bah! I'm already missing (S4).

[...] I have treadmill at home from time to time I do, but what I do is walking the $\operatorname{dog}(\mathrm{S} 5)$.

According to the testimony, the physical activities performed by respondents are aerobics and walking. However, only one interviewee said regular physical activity, the other members of the study just mentioned know their importance, but not often realize, is to dislike the activity or lack of time. Users who engage in physical activity emphasized like to accomplish, because it brings them welfare, improves sleep, so they miss when, for some reason, need to stop it.

In research with hypertension and diabetic people showed that the physical activity was also not present in most of the interviewees as a care to improve the health condition. ${ }^{12}$ The habit of not practicing physical exercise affect hypertension control and is directly related to weight gain. ${ }^{13}$ Physical inactivity is an attitude of modernity that requires a commitment to overcome it, considering that interfere with quality of life and, specifically, the quality of life of patients with hypertension. ${ }^{13}$

Data regarding physical activity, along with those presented in the previous categories, on the care and feeding medicated, may imply that the care practices developed by users of this research are closely related to their daily habits. Those care, 
they need to change routines and habits, they become difficult to perform, such as physical activity, reducing salt intake and taking medication.

In this sense, the authors point out that many human practices are constituted by cultural habits built into the routine, in their day-to-day. Thus, culture provides the elements for the events, practices of everyday life, including those relating to health are understood and accepted. ${ }^{21}$

It is necessary that health professionals "consider the sociocultural reality of the subject, in order to understand their life and care practices, and thus encourage them to take more control over their health.". 22:30

\section{Care in maintaining an emotional balance}

Another strategy used by users to beware of hypertension is related to maintaining emotional balance.

$[\ldots]$ Have a quieter life [...] I am a person who does not look to be getting involved with the discussion, do not like these things until now because of that (S1).

[...] Not very annoying, trying to turn a lot of things, try not to bother, that there is very good (S8).

The speeches presented indicate that uncomfortable, irritations, quarrels and arguments are factors that influence the uncontrolled hypertension. So, this study's participants seek to prevent such episodes occur as a strategy to keep your blood pressure controlled. As author ${ }^{16}$, "strategies" are forms of adjustment that people do on the chronicity. Over time, individuals identify situations and actions that influence the control or lack of control of their disease chronic, causing adopt strategies according to their experiences and experiences with the disease.

Other studies involving users with $\mathrm{SAH}$, found care practices similar to those demonstrated in this research. In these studies the emotional balance was achieved through actions such as prevention of stress, anxiety and other emotional distress situations. ${ }^{20,22}$ According to the Brazilian Guidelines on Hypertension, stress management is part of nonpharmacological treatment of hypertension, representing important role in decreasing blood pressure levels. ${ }^{4}$

\section{Popular care}

The popular care found were the use of teas and homemade recipes as a way to complement the conventional treatment of hypertension. About using teas have the following reports.

I was having tea artichoke, but not much, have to take soft spot and occasionally, when he feels the pressure is bad, take some tea artichoke (58). 
$[\ldots]$ I use on my own a lot of tea [...] but you cannot take too much, because I think it definitely gives me fall, makes me tremble [...] I do crush juice, because I believe: produces side effect that neither the chemical (S3).

I like tea, my sister fight a lot with me, that says that tea ... But I think not. Is that so: formerly cured only with teas, not because times have changed now that the tea will no longer take effect (S2).

The use of tea was reported as careful control of pressure, however, must be caution in its use. The amount, frequency and situations where they are used need to be complied with since they can cause side effects if taken excessively. The choice in the use of teas is performed autonomously, demonstrating not be an indication of health. Moreover, testimony shows confidence in the benefits of teas, as formerly were the only resources available for the treatment and cure of diseases.

The effects and benefits of teas are often unknown or ignored for being a resource by widespread popular knowledge. However, it is known that these teas are popular indications commonly confirmed by scientific research, as verified in a study on the use of medicinal plants. ${ }^{23}$

Apart from teas, were referred to other homemade recipes, according to users who help to keep blood pressure under control.

\section{[...] Water with sugar and cassava flour, is wonderful for the pressure! (S9)}

Grab a spoon cassava flour, put in a glass of water, stir and place in the refrigerator at dawn, when raises fasting conditions. I stayed a while and with it (blood pressure) so wonderful! (S2)

These practices are based alternatives by lay knowledge and empirical experiencedriven participants with these types of revenue and teas. In research on popular beliefs regarding health found that empirical experiments, based on positive or negative results obtained during the use of alternative resources advocated a credibility and adoption of these practices by the people. ${ }^{24}$

The popular features are usually used in order to solve health problems, being strongly influenced by sociocultural issues. Health professionals should encourage its use as a complement conventional treatment of hypertension, since the health practices of individuals are fruits of its integration in the sociocultural and historical. Studies show that it is necessary to understand the social care impounded for further elaboration care professionals. $^{18}$

Thus, (re) learn the social and cultural context of individuals who seek health institutions is becoming a requirement for health professionals seeking to offer a differentiated assistance in health, based on the completeness and uniqueness of each subject. ${ }^{24}$ 


\section{CONCLUSIONS}

The research helped identify the various forms of care developed by the participating users. In general, users have knowledge and awareness of care to be performed for the treatment of hypertension.

However, some care is difficult to show incorporated into everyday life, as they need changing habits and lifestyle, often culturally rooted. The control of the use of salt is one example, in various depositions was found that care is a challenge for the users. Likewise, the practice of physical activity was remembered as important, though the majority of respondents answered not perform often.

Thus, this research medical care proved to be the most valued and followed by users. Some lines have clearly that the medication is primary care. However, it also showed an oversight on its use for various reasons, such as forgetting, denial of the disease and also due to the absence of signs and symptoms attributed to hypertension.

Addition to these measures, the data showed that some participants seek to maintain emotional balance as a strategy for controlling blood pressure. Others use teas and homemade recipes. Thus, users resort to other forms of care, which are incorporated into other care for their own experience and familiarity with hypertension.

Finally, it is believed that the findings of this study may provide support for professionals conduct their actions in health together users with hypertension, particularly the actions of health education. It is necessary to enhance the practices used by these users and find, together with them, ways to overcome the difficulties and challenges posed by some measures considered essential for the control of hypertension and prevention of its complications.

\section{REFERENCES}

1. Cesarino CB, Cipullo JP, Martin JFV, Ciorlia LA, Godoy MRP, Cordeiro JA et al. Prevalência e fatores sociodemográficos em hipertensos de São José do Rio Preto - SP. Arq Bras Cardiol. 2008; $91(1):$ 31-5.

2. Toledo MM, Rodrigues SC, Chiesa AM. Educação em saúde no enfrentamento da hipertensão arterial: uma nova ótica para um velho problema. Texto e Contexto Enferm. $2007 \mathrm{abr} / \mathrm{jun} ; 16(2):$ 233-8.

3. Ministério da Saúde (BR). Secretaria de Atenção à Saúde. Departamento de Atenção Básica. Hipertensão arterial sistêmica para o Sistema Único de Saúde: Caderno de Atenção Básica $n^{\circ}$ 15. Brasília (DF); 2006. 
4. Sociedade Brasileira de Cardiologia. VI Diretrizes Brasileiras de Hipertensão. Rev Bras Hipertens. 2010 jan/mar; 17(1):1-69.

5. Saraiva KRO, Santos ZMSA, Landim FLP, Teixeira AC. Saber do familiar na adesão da pessoa hipertensa ao tratamento: análise com base na educação popular em saúde. Texto e Contexto Enferm. $2007 \mathrm{abr} / \mathrm{jun} ;$ 16(2): 263-70.

6. Boehs AE, Monticelli M, Wosny AM, Heidemann IBS, Grisotti M. A interface necessária entre enfermagem, educação em saúde e o conceito de cultura. Texto e Contexto Enferm. $2007 \mathrm{abr} /$ jun; 16(2): 307-14.

7. Langdon EJ, Wiik FB. Antropologia, saúde e doença: uma introdução ao conceito de cultura aplicado às ciências da saúde. Rev Latinoam Enferm [periódico on line]. 2010 mai/jun [citado 04 out 2012]; 18 (3): 173-9. Disponível em: http://www.scielo.br/pdf/rlae/v18n3/pt_23.pdf

8. Rosa LM, Silva AMF, Pereima RSMR, Santos SMA, Meirelles BHS. Família, cultura e práticas de saúde: um estudo bibliométrico. Rev Enferm UERJ. 2009 out/dez; 17(4):516-20.

9. Pires AP. Amostragem e pesquisa qualitativa: ensaio teórico e metodológico. In: Poupart J, Deslauriers JP, Groulx LH, Laperrière A, Mayer R, Pires AP. A pesquisa qualitativa: enfoques epistemológicos e metodológicos. Tradução de Ana Cristina Nasser. Petrópolis, RJ: Vozes; 2008.

10. Minayo MCS. O desafio do conhecimento: pesquisa qualitativa em saúde. 11 ed. São Paulo: Hucitec; 2010.

11. Ministério da Saúde (BR). Conselho Nacional de Saúde. Diretrizes e normas regulamentadoras da pesquisa envolvendo seres humanos: Resolução $n^{\circ}$ 196/96. Brasília (DF); 1996.

12. Brito RS, Santos DLA. Atitudes de cuidados desempenhadas por homens hipertensos e diabéticos com relação à sua saúde. Rev Pesqui Cuid Fundam (Online) [periódico on line]. 2012 jan/mar [citado 04 out 2012]; 4(1):2676-85. Disponível em: http://www.seer.unirio.br/index.php/cuidadofundamental/article/view/1638/pdf_478

13. Baldissera VDA, Carvalho MDB, Pelloso SM. Adesão ao tratamento não-farmacológico entre hipertensos de um centro de saúde escola. Rev Gaúch Enferm. 2009 mar; 30(1):27-32.

14. Ministério da Saúde (BR). Parceria com a indústria: Acordo para redução de sódio inclui novos alimentos. Brasília (DF); 2012. [citado 01 out 2012]. Disponível em: http://portalsaude.saude.gov.br/portalsaude/noticia/6829/162/acordo-para-reducao-desodio-inclui-novos-alimentos.html

15. Duarte MTC, Cyrino AP, Cerqueira ATAR, Nemes MIB, Iyda M. Motivos do abandono do seguimento médico no cuidado a portadores de hipertensão arterial: a perspectiva do sujeito. Ciênc Saúde Colet. 2010;15(5):2603-10.

16. Canesqui AM. Estudos Antropológicos sobre Adoecidos. In: Canesqui AM. (Org). Olhares socioantropológicos sobre os adoecidos crônicos. São Paulo: Hucitec:

Fapesp; 2007. p. 19-51.

17. Moreira AKF, Santos ZMSA, Caetano JA. Aplicação do modelo de crenças em saúde na adesão do trabalhador hipertenso ao tratamento. Physis [periódico on line]. 2009 [citado 04 out 2012]; $19 \quad$ (4): 989-1006. Disponível em:

http://www.scielo.br/pdf/physis/v19n4/v19n4a05.pdf 
18. Machado LRC, Car MR. Dialética do modo de vida de portadores de hipertensão arterial: o objetivo e subjetivo. Rev Esc Enferm USP [periódico on line]. 2007 [citado 30 set 2012]; 41(4):573-80. Disponível em: http://www.scielo.br/pdf/reeusp/v41n4/05.pdf

19. Mantovani MF, Ulbrich EM, Pinotti S, Giacomozzi LM, Labronici LM, Sarquis LMM. O significado e a representação da doença crônica: conhecimento do portador de hipertensão arterial acerca de sua enfermidade. Cogitare Enferm. 2008 jul/set; 13(3):336-42.

20. Baldissera VDA, Paludo D, Moreira NM, Garbelini LF, Carvalho MDB. Mudanças vivenciadas por hipertensos após o diagnóstico da doença. Rev Inst Ciênc Saúde [periódico on line]. 2008 jul-set [citado 30 set 2012]; 26(3):304-9. Disponível em: http://www.unip.br/comunicacao/publicacoes/ics/edicoes/2008/03_jul_set/V26_N3_2008_ p304-309.pdf

21. Leite SN, Vasconcellos MPC. Negociando fronteiras entre culturas, doenças e tratamentos no cotidiano familiar. Hist Ciênc Saúde - Manguinhos. 2006 jan-mar; 13(1): 11328.

22. Silva FM. "Hipertensão: eu aprendi a viver com ela" - relatos do saber construído como emancipação dos sujeitos. Santa Maria (RS): [s.n.], 2010, 145 p. Dissertação (Mestrado)Universidade Federal de Santa Maria; 2010.

23. Badke MR, Budó MLD, Silva FM, Ressel LB. Plantas medicinais: o saber sustentado na prática do cotidiano popular. Esc Anna Nery Rev Enferm [periódico on line]. 2011 jan/mar [citado 30 set 2012]; 15(1): 132-9. Disponível em: http://www.scielo.br/pdf/ean/v15n1/19.pdf

24. Siqueira KM, Barbosa MA, Brasil VV, Oliveira LMC, Andraus LMS. Crenças populares referentes à saúde: apropriação de saberes sócio-culturais. Texto e Contexto Enferm. 2006 jan/mar; 15(1): 68-73. 